\title{
Are financial reports useful? The views of New Zealand public versus private users
}

Dimu Ehalaiye*, Fawzi Laswad, Nives Botica Redmayne, Warwick Stent and Lei Cai School of Accountancy, Massey University, New Zealand

\section{*Corresponding author}

Dimu Ehalaiye, School of Accountancy, Massey University, Private Bag 11222, Palmerston North, New Zealand; email: o.ehalaiye@massey.ac.nz; phone: +64 69519020

Classification code: G10, G18, G20

Dimu Ehalaiye is a Senior Lecturer at the School of Accountancy, Massey University in New Zealand. Fawzi Laswad is Professor of Accountancy and Head of School at the School of Accountancy, Massey University in New Zealand. Nives Botica Redmayne and Warwick Stent are Senior Lecturers at the School of Accountancy, Massey University, New Zealand and Lei Cai is a Lecturer at School of Accountancy, Massey University, New Zealand. They are grateful to the External Reporting Board (XRB) New Zealand for access and permission to use the data collected for the two commissioned reports (XRB 2016 and XRB 2017) for the purposes of this research paper.

Accepted manuscript. Please cite this article as:

Ehalaiye, D., Laswad, F., Botica Redmayne, N., Stent, W., \& Cai, L. (2020). Are Financial Reports Useful? The Views of New Zealand Public Versus Private Users. Australian Accounting Review, 30(1), 52-64. 


\title{
Are financial reports useful? The views of New Zealand public versus private users
}

\section{Summary at a glance}

This paper examines perceptions of users of financial reports of public versus private forprofit entities in New Zealand. Results indicate that both user groups perceive financial statements to be useful but private users attribute higher importance to such statements. Both user groups also attribute different weightings to other supplementary information.

\begin{abstract}
This study reports on surveys conducted on users of financial reports in New Zealand. We compare findings for users of reports of two types of for-profit entities, namely those with public accountability (public entities) and those with no public accountability (private entities). The findings indicate that both types of users have similar perceptions regarding the usefulness of financial statements, with the income statement and balance sheet rated as the most useful components. Furthermore, both types of users, especially for private users, perceive financial statements as the most important information source for decision-making. Public users have a greater interest in supplementary information than private users. The findings of this study contribute to the debate around differential reporting for private companies and have policy implications with regard to the user-needs approach to accounting standards setting.
\end{abstract}

Keywords: Public users, private users, financial statements, accounting information 


\section{Introduction}

New Zealand statutory financial reporting obligations of for-profit entities vary based on entity size and whether or not the entity has public accountability. ${ }^{1}$ This study compares survey data from users of financial statements of entities that do have public accountability (hereafter public users) to that of users of financial statements of entities that do not have public accountability (hereafter private users). In particular, we consider the usefulness of the financial statements, user information sources and the importance users attach to supplementary information. ${ }^{2}$

The New Zealand Financial Reporting Act 2013 places financial reporting obligations on large for-profit entities. Large entities are defined as those having total assets exceeding $\$ 60 \mathrm{~m}$ or total revenue exceeding $\$ 30 \mathrm{~m}$. The External Reporting Board (XRB), the accounting standards-setting body of New Zealand, defines reporting obligations of for-profit entities in terms of two tiers. Tier 1 concerns entities with public accountability (public entities) which are generally required to apply International Financial Reporting Standards (NZ IFRS) in full. Tier 2 concerns entities with no public accountability (private entities), which may be required to apply a reduced disclosure regime based on IFRS (NZ IFRS RDR), depending mainly on size criteria.

A number of studies have examined how the financial reporting process is perceived from the preparers' perspective (e.g., Jermakowicz and Gornik-Tomaszewski 2006; Andriani et al. 2010; Navarro-García and Bastida 2010; Morris et al. 2013; Laswad and Botica Redmayne 2015), the consequences and effects of the financial reporting process and accounting information (e.g., Jermakowicz et al. 2007; Horton et al. 2011; Brochet et al. 2013), the user information needs of large public entities (e.g., Lee and Tweedie 1975a; McNally et al. 1982; Gassen and Schwedler 2010), and the user information needs of smaller (private) entities (e.g., Maingot and Zeghal 2006; Quagli and Paoloni 2012). However, there is a significant gap in the literature with regard to a comparative study between the user information needs of public entities and private entities, especially in light of the arguments made for reduced disclosures and differential reporting for private entities. The motivation for this study is, therefore, to provide direct evidence by comparing financial report users of public and private entities, in particular, their information needs and perceptions. 
The XRB financial reporting framework, which is based on the International Accounting Standards Board (IASB) framework, identifies meeting user needs as the primary focus of financial reports. To this end, the XRB has published separate reports examining the information needs of users of financial reports of capital market entities (public entities), followed by a report examining users of tier 2 for-profit entities with no public accountability (private entities) (XRB 2016; XRB 2017).

The data in this study is extracted from the two studies commissioned by the XRB (XRB 2016; XRB 2017) and compares the perceptions of the users of the financial reports of these two types of entities - public and private. We find the perceptions of usefulness of financial statements of public users are similar to those of private users. However, the two user groups attribute different weightings to the importance of their sources of information. In addition, private users rate narratives that explain the entity's performance and financial position as the most useful type of supplementary information not currently included in financial statements.

The remainder of the paper is organised as follows: Section 2 provides a literature review, which is followed by the research design in section 3 . The findings are presented in section 4 section 5 concludes the paper.

\section{Literature review}

The IASB conceptual framework state that the objective of general purpose financial reporting is to provide financial information about the reporting entity that is useful to existing and potential investors, lenders and other creditors in making decisions about providing resources to the entity (IASB 2010: 9). Based on this objective of financial reporting, there is a need to consider who the users of these financial reports are and what sort of information they need, given that, the goal of financial reports is to provide these users with useful information (Rankin et al. 2012: 33).

The primary users of financial reports identified in the IASB conceptual framework include existing investors, potential investors, lenders and other creditors. It is acknowledged, however, that financial reports could be useful to other user groups, but that the focus of the information provided in financial reports is on the primary users ${ }^{3}$ (IASB 2010: 11). Prior literature has identified other user groups that are interested in general purpose financial 
reports as including intermediaries, advisors and financial market and prudential regulators (Coombes and Stokes 1985; Barker and Noonan 1996; XRB 2016). Further, the information in financial reports is focused mainly on financial information from specific financial statements. These include a statement of financial position (balance sheet), a statement of profit or loss and other comprehensive income (income statement), a statement of cash flows, a statement of changes in equity and the notes to the financial statements (Rankin et al. 2012: 34). The conceptual framework does not consider other non-financial information and supplementary information that users may be interested in (Andon et al. 2015). Furthermore, the conceptual framework does not discuss whether the information needs of users of financial statements of entities that do have public accountability (public users) are different from the needs of users of financial statements of entities that do not have public accountability (private users). It is therefore important to investigate the views and perceptions of these users' needs for financial statements.

\subsection{User perceptions of the usefulness of financial reports}

An extensive body of literature has addressed the accounting information needs of public users. Several early studies examine user information needs in the United States (US), the United Kingdom (UK), and Australia and focus on private/individual users. They find that equity investors are primarily concerned with expectations about future earnings and cash flows (Baker and Haslem 1973; Lee and Tweedie 1975a; Chenhall and Juchau 1977; Anderson 1981).

In the US, Baker and Haslem (1973) examined whether the information provided in financial reports meets the needs of individual investors. They find that US investors are primarily concerned with expectations about future earnings. Providing profit forecasts, as part of the prospective information, reduces investor uncertainty regarding future returns. Similarly, Lee and Tweedie (1975a) find that the economic prospects of a company are the most important items of information to UK individual investors. A survey by Chenhall and Juchau (1977) suggests that Australian investors consider seven factors to be important. Three of these relate to prospective matters - expected future increase in share price, future economic outlook of the company and industry, and expected future growth in earnings per share (EPS). 
A stream of studies has also examined the information needs of professional/institutional equity investors, who are generally considered to have more expertise and resources for analysis of financial information than private/individual investors. Baker and Haslem (1973) comment that individual investors appear to have different information needs from professional analysts and rely less on financial reports than professional analysts do. However, individual investors are found to be dependent on the advice provided by professional analysts. Subsequent studies (Barker 1998; Imam et al. 2008) reach similar conclusions.

Chandra (1974) used a questionnaire to examine whether public accountants (as the preparers of financial information) and security analysts (as the users of financial information) agree on the importance of various information items in equity investment decisions. He finds that accountants generally do not value information in the same way as security analysts do. For example, they differ with respect to the need for detail and breakdown of inventories, investments, earnings from subsidiaries and operating expenses.

More recently, PwC (2014a, 2014b) conducted a series of surveys to investigate the needs and opinions of investment professionals about maximising the effectiveness of corporate reporting. Based on interviews with 85 professional investors around the world, PwC (2014a) finds that most professional investors consider adjusted performance measures (non-GAAP) helpful for their analysis, but they recommend improved transparency of disclosure. PwC (2014b) finds that there is little consensus among professional investors about their preferences for the presentation, format, and layout of financial reports. Professional investors indicate that accounting policies should be easy to find and disclosures should be company-specific with a useful level of detail.

Chartered Financial Analysts UK (CFA UK 2015) conducted a survey of more than 290 investment professionals on the importance of annual reports and other forms of company reporting. The results of that study show that $60 \%$ of respondents believe financial reports contain too much irrelevant information, but 55\% feel financial reports omit some important information, and $47 \%$ assert that the disclosure of risks and uncertainties should be improved. These inconsistencies provide evidence that the perceived importance of information is very much a reflection of personal preference. However, overall most respondents agree that the 
quality of financial reporting has improved over the last 10 years (i.e., the period since IFRS adoption in many countries around the world).

The body of literature examining the information needs of private users is less extensive (e.g., Abdel-Khalik et al. 1983; Carsberg et al. 1985; Barker and Noonan 1996; Page 1984; FERF 2006; Handley et al. 2017). However, most of these studies identify primary users as including insider shareholders (owners and managers), banks, tax authorities, and some others (e.g., insurance companies, leasing companies, and vendors).

\subsection{Information sources}

Users of accounting information also use information sources other than financial reports. Investors, whether individual or professional, rely on a variety of sources to satisfy their information needs (Watts 1977; Anderson et al. 2012). Much of the evidence in the prior literature on sources of equity investor information shows that individual investors are more likely to use public media, analysts' advice, and advice from friends and family members than to use financial reports for investment decisions. There is, however little consistency in prior studies as to how users rank these different sources in terms of importance.

In an early US study, Baker and Haslem (1973) find that individual investors consider stockbrokers and advisory services as the most important sources for their investment information and attach minor importance to published financial reports as a source of information. On the other hand, in the UK, Lee and Tweedie (1975a) find that most respondents regard annual reports as an important source of information for investment decisions and that financial press reports, followed by stockbrokers' reports are also considered particularly important.

The results in Lee and Tweedie (1975a) elaborate on how investors use annual reports, suggesting that private shareholders tend to skim through them and focus on the chairman's report. Bartlett and Chandler (1997) partially replicate the Lee and Tweedie (1975a) study in examining the readership of annual reports for a sample of UK private shareholders. Their results indicate that annual reports are not widely read by private shareholders, despite significant changes in financial reporting since the 1970s. Lee and Tweedie (1975b) investigate private shareholders' understanding of accounting practice and find that those shareholders 
with more knowledge or experience of accounting are more able to understand financial reports than those with less knowledge or experience. A later survey by Elliot et al. (2008) finds that less experienced non-professional investors who use unfiltered (raw) information, earn lower returns than more experienced investors. ${ }^{4}$

Anderson (1981) finds that Australian institutional investors rank annual reports as the most important source of information, followed by sharebrokers' advice and company visits. The most widely read sections of the financial report are the balance sheet, profit and loss statement, notes to the accounts, and chairperson's address. Similarly, Day (1986) finds that UK investment analysts perceive the annual report to be an important document, but not a timely source of price sensitive information. Further, surveys by Vergoossen and Amsterdam (1993) in the Netherlands, and by Conesa and Martinez (2004) in Spain, find that the annual report appears to be vital to investment analysts, who emphasise the importance of the consolidated balance sheet and income statement. More recently, Gassen and Schwedler (2010) also find that professional investors and their advisors in 22 countries generally view annual financial statements as the most relevant information source, followed by direct personal contact with investee management, notes to the financial statements, and quarterly financial statements.

One possible explanation for the increased perceived usefulness of financial reports, at least for professional investors, is the adoption of IFRS around the world, and there is some evidence in the literature supporting consequent improvements in the quality of reported financial information. In New Zealand, McNally et al. (1982) find that professional users, as compared to financial editors and stock exchange members, attribute different importance levels to more detailed disclosure of specific items, but that few of these differences are statistically significant. A survey of users in 10 European countries by the European Financial Reporting Advisory Group (EFRAG) indicates that most users consider financial statements and management commentary to be the most useful sources of financial information, as compared to press releases, economic surveys, and market information (EFRAG 2009).

PricewaterhouseCoopers (PwC 2011) finds that while the annual report is still seen by many as an invaluable source for providing detailed information about firm performance, it is no longer viewed by investment professionals as the document of record that provides the cornerstone for all valuation work. To improve the quality of disclosure, investment 
professionals indicate a need for more disaggregation in segment reporting, and more coherent, consistent information between narrative sections of the annual report and the audited financial statements. A CFA UK (2015) study reveals that investment professionals find annual reports to be the most useful source of financial information, followed by databases (e.g., Bloomberg) and sell-side research reports.

\subsection{Other supplementary information}

The growing importance of management's commentary on a business and its results is evident in various developments around the globe. Examples include requirements in the US for management discussion and analysis to accompany the financial report, in the UK for directors' reports to include a business review, in Australia for an "operating and financial review" to be included in the annual report (ASIC 2013), and in South Africa for listed entities to produce an integrated report (Stent and Dowler 2015).

New Zealand requirements are currently lagging in this regard. Requirements for the contents of an annual report are specified in section 211 of the Companies Act $1993 .{ }^{5}$ There is no specific requirement for a director's report or management discussion and analysis, although the board of directors is required to provide details of material changes in the nature or classes of the business of the company (Deloitte 2011). Listed entities on the NZX are required to provide commentary on the results for the period in a preliminary announcement in respect of a full year. Many entities meet this requirement by including the necessary information in a chairman's or director's report (Deloitte 2011).

In this study, we examine the perceptions of public versus private users in relation to the usefulness of the financial statements, the information sources used in decision-making, and the need for other supplementary information.

\section{Research design and study sample}

\subsection{Reporting entities in New Zealand}

Figure 1 below provides an overview of the total population of reporting entities in the context of the wider for-profit business environment in New Zealand. 


\section{Insert Figure 1 about here}

It is estimated that in 2015 , there were 444,060 for-profit business enterprises in New Zealand. The total number of for-profit entities with reporting obligations is estimated at 2,575 (i.e., a little over 0.5\%), with 329 of these being Tier 1 entities and 2,246 being Tier 2 entities. While the Tier 1 population could be determined accurately, estimation of the Tier 2 population was more difficult, because there is no formal requirement for such firms to register or file returns (XRB 2017). To complicate matters further, legislation such as the Companies Act (section 200) allows entities to opt into and out of a Tier under certain circumstances. This data provides evidence that the XRB's reporting strategy indeed excludes the higher reporting costs associated with IFRS for over $99 \%$ of for-profit entities in New Zealand. According to XRB (2017), the bulk of the remaining $1 \%$ of the population has the option of some reduction in mandatory reporting costs by opting to apply IFRS RDR $(2,246$ entities). Prior literature indicates that there is little consistency regarding the views and needs of different users as to how to achieve further reductions in reporting costs without sacrificing information, which some users find useful for their particular purposes.

As noted above, it is difficult to estimate the population of the bulk of New Zealand's reporting entities (i.e., Tier 2). Even more difficult would be to estimate the populations of the users of reports for these reporting entities. We do not attempt such an estimate but explain below how we conduct a survey designed to access the entire population of users.

\subsection{The surveys}

Two online questionnaires were developed for the surveys, one for public users (XRB 2016) and the second for private users (XRB 2017). Public users in the New Zealand context are users of financial statements of entities (Tier 1 entities) that do have public accountability and private users are users of financial statements of entities (Tier 2 entities) that do not have public accountability. Survey questions explored the usefulness of financial statements, the importance of other sources of information used in making decisions, and the importance of other supplementary information in financial statements. The questions are shown in the 
appendix to this paper. Questions included use of a five-point rating scale, from 1 (very low) to 5 (very high), asking respondents to allocate $100 \%$ among the various options with regard to the types of decisions they make and the sources of information they use, and 'Yes' or 'No' questions with the opportunity to provide further explanation.

Before launching the online surveys, a pilot test of the questionnaires was conducted to identify and resolve potential issues such as ambiguity or bias. The data for this study were part of two larger studies commissioned in the years 2016 and 2017 by the XRB that examined the information needs of users of New Zealand capital markets' entity reports (Tier 1) and Tier 2 for-profit entities' financial reports, respectively.

\subsection{The respondents}

The two surveys were launched online using a variety of approaches to reach the different user groups and encourage responses. These approaches included links to the survey through various digital and print media channels; email invitations to commercial officers in major banks, brokers, and fund managers; invitations to potential respondents through various professional organisations and accounting firms to access their members/client bases; and email invitations to relevant regulators. In theory, this enabled us to make the survey accessible to the entire population of GPFR users in each of the user groups. This approach resulted in good sized samples but did not allow the calculation of response rate percentages.

The surveys resulted in 47 useable responses from private users and 115 useable responses from public users. ${ }^{6}$ These sample sizes compare very favourably with similar recent studies in the UK and the European Union. ${ }^{7}$

Table 1, Panel A, provides descriptive information on these two types of users, while Panel $B$ shows self-ratings of their knowledge and experience (where 1 is very low and 5 is very high). Most respondents have above average levels of knowledge, skills, and experience in reading, understanding and analysing financial statements (means are above 3 for both knowledge and experience for both private and public users). There is a marginally significant statistical difference between the knowledge and skills of the two user types, suggesting that the users of private entity financial statements have more knowledge of financial statements than the users of public entity financial statements. This may be because financial statements 
are relied upon more by private users than public users, who tend to prefer the use of other sources of information for their decision-making. However, our samples show no significant statistical differences in experience between the two user types, suggesting that private users are as experienced when compared to public users in their reading, understanding and analyses of financial statements.

Table 1 Descriptive information on user samples surveyed

Panel A: User type and group

\begin{tabular}{|c|c|c|c|}
\hline & \multicolumn{2}{|c|}{ User } & \multirow[b]{2}{*}{ Total } \\
\hline & Public & Private & \\
\hline Advisor & 52 & 11 & 63 \\
\hline Investor & 37 & 10 & 47 \\
\hline Lender & 19 & 11 & 30 \\
\hline Regulator & 7 & 7 & 14 \\
\hline \multirow[t]{2}{*}{ Others } & $\underline{0}$ & 8 & 8 \\
\hline & 115 & 47 & 162 \\
\hline
\end{tabular}

Panel B: Knowledge and skills

\begin{tabular}{lcccc}
\hline & \multicolumn{2}{c}{ Public } & Private \\
& Mean & Standard Deviation & Mean & Standard Deviation \\
\hline Knowledge & 3.887 & 0.814 & $4.11^{* *}$ & 1.07 \\
Experience & 3.878 & 0.870 & 3.94 & 1.07 \\
\hline
\end{tabular}

Significant at ${ }^{* *} \alpha=0.05$

Insert Figure 2 about here.

\section{Results and Discussion}

Mean responses for the questions were calculated and where appropriate used for rankings to summarise the degree of usefulness and importance that respondents attribute to the issues raised in the questionnaires. The higher the mean, the higher the usefulness/ 
importance as perceived by the respondents. The Mann-Whitney $U$ test is used to provide a basis for comparison of public versus private users' responses to the questions. Lastly, to evaluate the degree of association between the responses of the two user types regarding the usefulness of components of financial statements specifically, we compute the Kendall Rank Correlation Coefficient $(\tau)$ for the ranked means of their responses to that specific question.

\subsection{Types of decisions for which financial reports are used}

Table 2 reports the weighting (out of 100) of the various decision types for which financial reports are used. There are significant differences between the two types of users. While the making of equity and debt investments are the most important decisions for public users (means of $46.74 \%$ and $17.79 \%$ respectively), the monitoring of management performance (mean of $24.22 \%$ ) is most important for private users. This highlights that private entities tend to have closely held shares and a lower percentage of debt in capital structure compared to public entities, hence private users' tendency to use financial reports more for monitoring management and governance, rather than for equity and debt investment. Private users also attributed a high weighting of approximately $20 \%$ to other decisions, compared to $6 \%$ weighting to other decisions by public users. This shows the heterogeneity of private users' needs for financial statements in comparison to public users. Specifically, such other decisions that private users use financial statements for, include compliance with regulations and tax, assessing the performance of the organisation, evaluating of projects, and monitoring compliance of covenants. This is consistent with Barker and Noonan (1996) who identify that the three most important groups of users of financial statements of small companies (SMEs) are owners/directors, banks, and the tax authority. This finding also supports the findings of Eierle and Haller (2009) that most SMEs see little or no need to provide internationally comparable financial statements. 


\begin{tabular}{|c|c|c|c|c|c|}
\hline & & \multicolumn{2}{|c|}{ Public ( $N=115)$} & \multicolumn{2}{|c|}{ Private $(\mathrm{N}=47)$} \\
\hline & & Mean (\%) & $\begin{array}{c}\text { Standard } \\
\text { Deviation (\%) }\end{array}$ & Mean (\%) & $\begin{array}{c}\text { Standard } \\
\text { Deviation (\%) }\end{array}$ \\
\hline- & Decisions - Equity investment & 46.74 & 37.13 & $16.35^{* * *}$ & 26.40 \\
\hline- & Decisions - Debt investment & 17.79 & 26.14 & $5.93 * * *$ & 11.87 \\
\hline- & $\begin{array}{l}\text { Decisions - Lending or extension of } \\
\text { credit }\end{array}$ & 16.50 & 33.21 & 16.56 & 29.60 \\
\hline- & $\begin{array}{l}\text { Monitoring performance for } \\
\text { management }\end{array}$ & 11.49 & 17.93 & $24.22 * * *$ & 24.58 \\
\hline- & $\begin{array}{l}\text { Monitoring performance for } \\
\text { governance }\end{array}$ & 9.14 & 13.17 & 17.02 & 23.23 \\
\hline- & Other decisions & 6.39 & 19.94 & $19.89 * *$ & 37.16 \\
\hline
\end{tabular}

Significant at ${ }^{* *} \alpha=0.05 ; * * *$ at $\alpha=0.01$

\subsection{Usefulness of components of financial statements}

Table 3 reports the level of usefulness of each of the components of the financial statements. The results indicate that all financial statement components are rated as useful (mean rating of 2.99 or more) for both private and public users. However, the level of usefulness is higher for some components than for others. The income statement followed closely by the balance sheet are the two most useful components of the financial statements for both private and public users. Cash flows are ranked next, followed by the notes to the financial statements. A Mann-Whitney $U$ test indicates no significant differences in these ratings between public and private users, suggesting that both groups regard the usefulness of the components of the financial statements similarly. 
Table 3 Usefulness of components of financial statements

\begin{tabular}{|c|c|c|c|c|c|}
\hline & \multirow[b]{2}{*}{ Rank } & \multicolumn{2}{|c|}{ Public ( $\mathrm{N}=115)$} & \multicolumn{2}{|c|}{ Private $(\mathrm{N}=47)$} \\
\hline & & Mean & $\begin{array}{l}\text { Standard } \\
\text { Deviation }\end{array}$ & Mean & $\begin{array}{l}\text { Standard } \\
\text { Deviation }\end{array}$ \\
\hline Income statement & 1 & 4.37 & 0.90 & 4.36 & 0.82 \\
\hline Balance sheet & 2 & 4.25 & 0.97 & 4.36 & 0.87 \\
\hline Cash flows & 3 & 3.90 & 1.29 & 3.94 & 1.19 \\
\hline Notes & 4 & 3.75 & 1.15 & 3.77 & 1.34 \\
\hline Changes in equity & 5 & 2.99 & 1.29 & 3.21 & 1.35 \\
\hline
\end{tabular}

Table 4 Associations between the usefulness ratings of financial statement components

\begin{tabular}{|c|c|c|c|c|c|}
\hline & Sample & Balance sheet & $\begin{array}{c}\text { Income } \\
\text { statement }\end{array}$ & $\begin{array}{c}\text { Changes in } \\
\text { equity }\end{array}$ & Cash flows \\
\hline \multirow[t]{3}{*}{ Income statement } & Total & $0.466^{* *}$ & & & \\
\hline & Public & $0.394^{* *}$ & & & \\
\hline & Private & $0.647^{* *}$ & & & \\
\hline \multirow[t]{3}{*}{ Changes in equity } & Total & $0.291^{* *}$ & $0.284^{* *}$ & & \\
\hline & Public & $0.248^{* *}$ & $0.227^{* *}$ & & \\
\hline & Private & $0.377^{* *}$ & $0.422^{* *}$ & & \\
\hline \multirow[t]{3}{*}{ Cash flows } & Total & $0.149^{*}$ & $0.141^{*}$ & $0.288^{* *}$ & \\
\hline & Public & 0.115 & 0.115 & $0.287^{* *}$ & \\
\hline & Private & 0.232 & 0.203 & $0.291^{*}$ & \\
\hline \multirow[t]{3}{*}{ Notes } & Total & $0.141^{*}$ & $0.186^{* *}$ & $0.241^{* *}$ & $0.217^{* *}$ \\
\hline & Public & 0.050 & 0.064 & $0.177^{*}$ & $0.201^{*}$ \\
\hline & Private & $0.336^{* *}$ & $.480^{* *}$ & $0.369^{* *}$ & $0.256^{*}$ \\
\hline
\end{tabular}

Significant at ${ }^{*} \alpha=0.10 ;{ }^{* *} \alpha=0.05 ;{ }^{* *} \alpha=0.01$ 
Table 4 reports the Kendall Rank Correlation Coefficients between the usefulness ratings for the components of the financial statements. The coefficients are positive and significant for public and private users except for the association of notes to the financial statements with the balance sheet and the income statement for public users, and the association of cash flows with the balance sheet and the income statements for both user types. This is consistent with prior research by Yap (1997) that found evidence from a survey of financial statement users in Australia suggesting that cash flow statements are regarded as being of considerable assistance in helping users assess liquidity, solvency and financial flexibility, although not surpassing the importance of information relating to future prospects and profit levels. Further, the notes to the financial statements of public entities have been found to be difficult to read. Reasons from prior literature include that they are perceived as lengthy, complex, and contain technical terms and multi-syllable words (Barnett and Leoffler 1979; Courtis 1986; Courtis 1995; Li 2008; Cheung and Lau 2016). Furthermore, large companies (usually public entities) are perceived as providing less readable notes than small companies (usually private entities) (Healy 1977). This may explain why the usefulness of the notes to the financial statements is not associated with that of the balance sheet and the income statement for public users, as reported in Table 4.

\subsection{Sources of information}

Table 5 summarises which key sources of information are used in making decisions. Respondents were asked to allocate $100 \%$ between these sources of information to indicate their relative importance. Mean percentage of importance is presented for each source of information. Both types of users rate financial statements as the most important source of information, although private users rate the financial statements significantly higher (at 49.2\%) than public users (at $36.85 \%$ ). This reinforces the greater reliance which private users place on the information provided in the financial statements.

Public users place greater importance on advisors and analysts' reports (29.4\%) compared to private users (13.86\%). Public users also use the media (11.32\%) as an important source of information compared to private users (7.72\%). This is consistent with the greater focus of analysts and the media on public companies (Baker and Haslem 1973; Courtis 1982). 


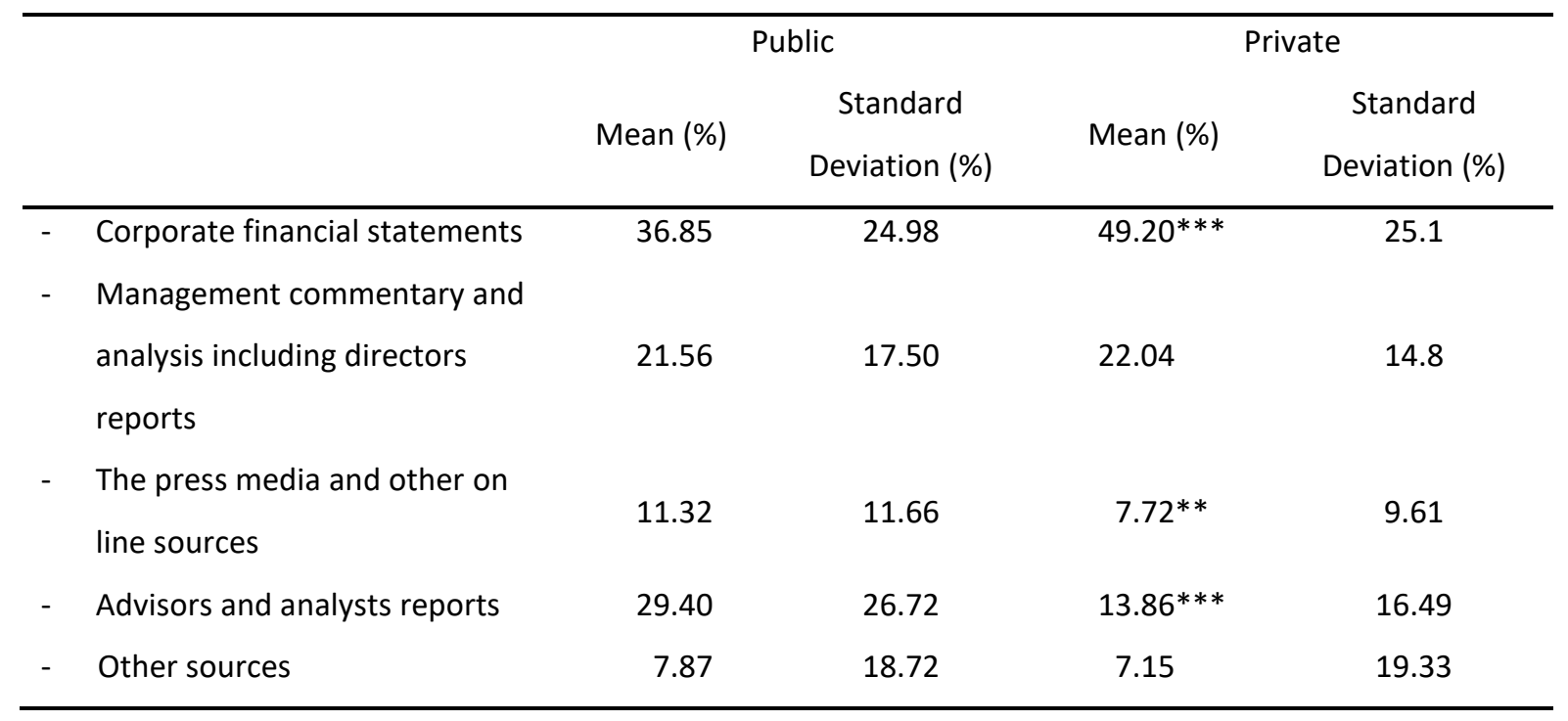

Significant at ${ }^{* *} \alpha=0.05 ;{ }^{* *} \alpha=0.01$

Insert Figure 3 about here.

\subsection{Interest in supplementary information}

The respondents were asked whether they are interested in information not currently included in financial statements (supplementary information). Panels A and B of Table 6 report their level of interest and ratings of the usefulness of a range of other such information. Panel A indicates that public users (54\%) have significantly more interest in supplementary information than private users (38\%).

Panel B of Table 6 shows the mean usefulness of various types of supplementary information using a scale of 1 (least useful) to 5 (most useful), based only on the responses of the survey participants who responded in the affirmative to having an interest in supplementary information as shown in Panel A.

Overall, both private and public users who have an interest in supplementary information, rank all supplementary information types as being useful (mean above 3), except for narratives that explain the entity's performance and financial position which is the least useful for public users (mean $=1.19$ ). This contrasts strongly with the private users, who ranked such narratives as the most important type of supplementary information (mean $=3.94$ ), a 
difference which is strongly significant (0.01). This reflects the fact that public users have access to a wider range of information than private users. This finding also provides evidence in support of narrative reporting for private users as such narrative reporting contains important management's communication with stakeholders. Weetman (2018:157) suggests that recent "proposals for such disclosure are strongly normative and tend to be based on the beliefs and good intentions of interested groups, rather than on hard evidence of what is actually useful to stakeholders". This study provides evidence that supports such additional disclosures.

Table 6 Supplementary information

Panel A: Interest in supplementary information

\begin{tabular}{lcccccc}
\hline & Public & \multicolumn{3}{c}{ Private } & & \multicolumn{2}{c}{ Total } \\
& $N$ & $\%$ & $N$ & $\%$ & $N$ & $\%$ \\
\hline No* $^{*}$ & 53 & $46 \%$ & 29 & $62 \%$ & 82 & $51 \%$ \\
Yes* & $\underline{62}$ & $\underline{54 \%}$ & $\underline{18}$ & $\underline{38 \%}$ & $\underline{80}$ & $\underline{49 \%}$ \\
& 115 & $100 \%$ & 47 & $100 \%$ & 162 & $100 \%$ \\
\hline
\end{tabular}

Significant at ${ }^{*} \alpha=0.10$

Panel B: Interested users' assessments of the usefulness of supplementary information

\begin{tabular}{|c|c|c|c|c|}
\hline \multirow[b]{2}{*}{ Supplementary information } & \multicolumn{2}{|c|}{ Public ( $N=62$ ) } & \multicolumn{2}{|c|}{ Private $(\mathrm{N}=18)$} \\
\hline & Mean & Standard & Mean & Standard \\
\hline - $\quad$ Entity's business & 3.694 & 1.154 & 3.222 & 1.629 \\
\hline $\begin{array}{l}\text { - Narratives explaining the entity's } \\
\text { performance and financial position }\end{array}$ & 1.194 & 1.763 & $3.944 * * *$ & 1.110 \\
\hline $\begin{array}{l}\text { - Business strategies and prospects } \\
\text { for future financial years }\end{array}$ & 4.371 & 0.910 & 3.889 & 1.410 \\
\hline - Summary financial information & 3.419 & 1.235 & 3.529 & 1.419 \\
\hline
\end{tabular}

Significant at ${ }^{* *} \alpha=0.05 ; * * *=0.01$ 


\subsection{Summary of main differences between public and private users}

Table 7 below provides a summary of the main differences, identified and discussed in the preceding sub-sections, between the information needs of public and private users of financial statements.

Table 7 Summary of main differences between public and private users

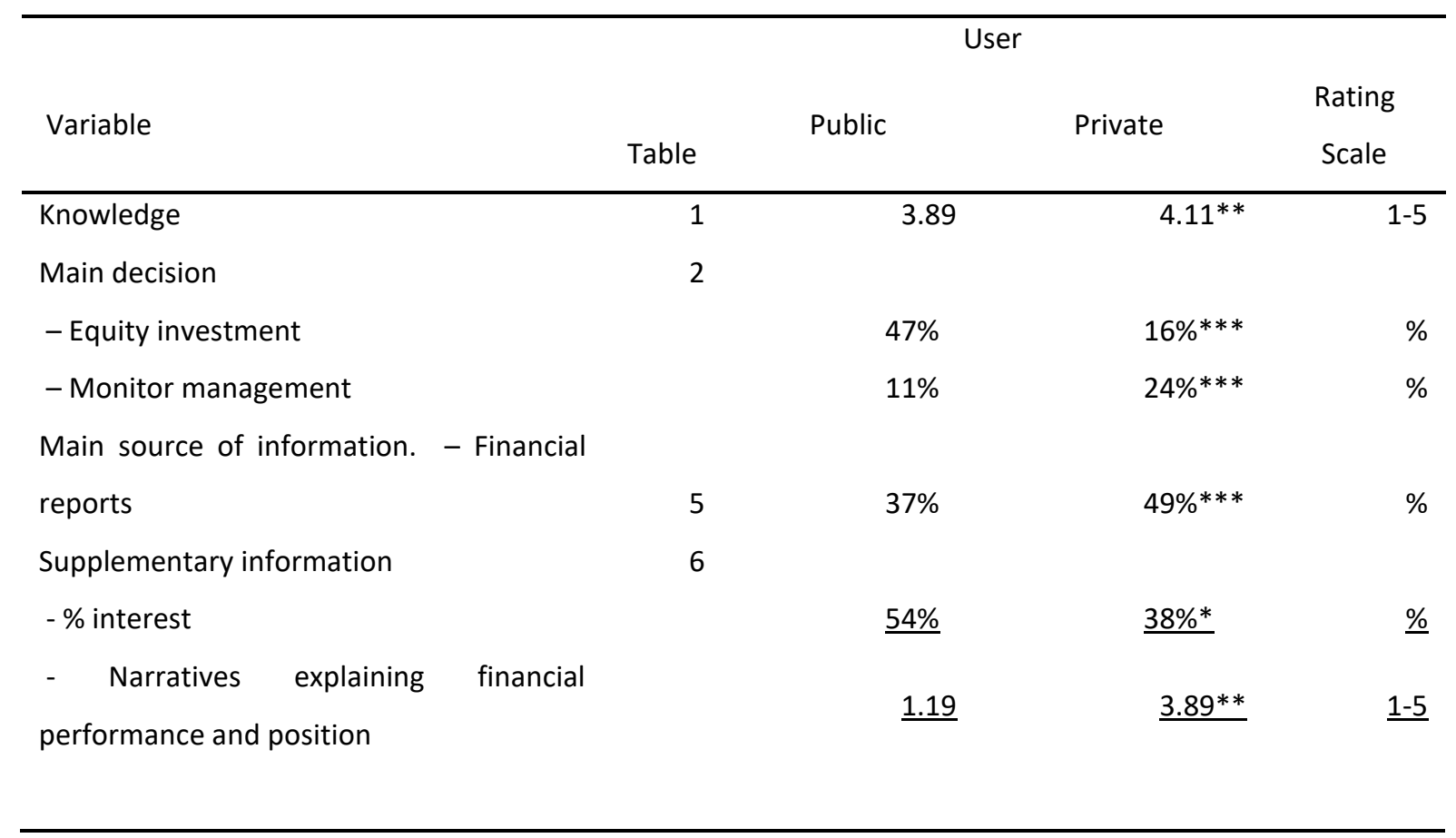

Significant at ${ }^{*} \alpha=0.10,{ }^{* *} \alpha=0.05 ;{ }^{* * *}$ at $\alpha=0.01$

In summary, our findings suggest that public (private) users in the study sample are less (more) knowledgeable about financial reports and use them mainly to make equity investment decisions (monitor management performance). Our findings also indicate that while both types of users rate financial reports as their main source of information, public users rely on them less, obtaining $37 \%$ of their information from financial reports (private users: $49 \%)$.

User views differ significantly regarding the need for supplementary information in that public (private) users are more (less) interested in supplementary information, except as regards 
narratives which explain financial performance and position where the usefulness of narratives is rated at 1.19 (3.89).

\section{Conclusion}

The financial reporting obligations of New Zealand's for-profit entities are based on the size of assets and revenue and whether or not they have public accountability. Entities with public accountability report under Full IFRS (Tier 1), while entities with no public accountability may be required to report under a reduced disclosure regime based on IFRS, depending mainly on their size.

We compared the survey responses of users of financial reports of entities that have public accountability (Tier 1) with those of users for entities with no public accountability (Tier 2 ). Our findings indicate that both user types have similar perceptions regarding the usefulness of financial statement components, with the income statement and balance sheet rated as most useful, followed by the cash flow statement and then the notes to the financial statements. The statement of changes in equity is regarded as least useful.

Both public and private users rate financial statements as the most important source of information, although private users do place greater importance on this source of information. Public users place greater importance on media and analysts' reports as sources of information compared to private users. This can be explained by the availability of such information for public entities.

A higher proportion of public users have an interest in supplementary information than private users. Information about business strategies and future prospects is rated as most useful for public users and as the second most useful source of supplementary information for private users. Narratives that explain the entity's performance and financial position is rated as the most useful supplementary information for private users but as least useful for public users. This could be explained by the greater level of access, which public users have to the analysts' and media reports that provide such information. 
The findings of this study provide useful incremental insights into the users' perspectives on the usefulness of financial statements, an area that has been under-researched, especially in recent times. The findings of this study are of potential interest to policy makers and regulators of financial reporting when keeping in mind the quality of information provided in the financial statements and the costs and benefits of financial reporting regulation.

The limitations of this study revolve around the restricted nature of the surveys conducted, as the surveys were completed only by financial statements users in New Zealand and therefore the survey findings might be specific to the New Zealand financial reporting environment and not simply transferrable to other jurisdictions and reporting environments.

\footnotetext{
${ }^{1}$ In the US, a private company is not required to provide any information to the public. However, in Australia and the UK, large private companies that meet two of three criteria based on revenue, assets and number of employees, are required to prepare and lodge financial reports.

${ }^{2}$ The New Zealand Framework defines public accountability in accordance with the International Accounting Standards Board's definition of an entity that has debt or equity instruments traded in a public market or holds assets in a fiduciary capacity for a broad group of outsiders as its primary businesses.

${ }^{3}$ The US Financial Accounting Standards Board (FASB) conceptual framework also identified the same set of primary users for financial reports (FASB 2010:3).

${ }^{4}$ Elliot et al. (2008) classify information as "filtered" and "unfiltered". Filtered information is information packaged by a professional intermediary for consumption by investors (e.g., analysts' reports) while unfiltered information is information disclosed by management and unaltered by professional intermediaries (e.g., a firm's annual report).

${ }^{5}$ Companies Act 1993, extracted 15/4/2015 from: http://www.legislation.govt.nz/act/public/1993/0105/latest/DLM321118.html

${ }^{6}$ Not all respondents answered all survey questions. The tables therefore report the number of responses to each question.

${ }^{7}$ EFRAG (2009) had 32 respondents from 10 countries in the European union in their survey of public firms, while CFA UK (2015) surveyed about 290 investment professionals who deal with listed firms in the UK. Quagli and Paoloni (2012) analysed a European Commission survey of only 25 respondents across the European Union who use the financial statements of private firms based on IFRS for SMEs.
} 


\section{Appendix: The questionnaire}

Q1 Your knowledge, skills and experience

How would you describe your level of your knowledge, skills, and experience in reading, understanding and analysing financial statements? Please use the scale where 0 indicates none and 5 very high.

Knowledge and Skills

Experience

Q2 Types of decisions for which you use financial reports

For what types of decisions do you use corporate financial reports? Please allocate $100 \%$ among the various types of decisions you undertake to indicate their approximate level of importance.

Equity investment

Debt investment

Lending or extension of credit

To monitor/assess performance of those responsible for governance

To monitor/assess performance of those responsible for management

Others, please specify as many categories as you see relevant and indicate their importance

Q3 The usefulness of components of financial statements

The items below comprise a full set of financial statements. Please rate the usefulness of each item to you in making decisions. Please use the scale 1 to 5 , where 5 is the most useful. Please support your responses by providing reasons in the space below each item.

\begin{tabular}{|c|c|c|c|c|c|c|}
\hline & $\begin{array}{l}1 \text { (Least } \\
\text { useful) }\end{array}$ & 2 & 3 & 4 & $\begin{array}{l}5 \text { (Most } \\
\text { useful) }\end{array}$ & $\begin{array}{l}\text { N/A or do } \\
\text { not know }\end{array}$ \\
\hline $\begin{array}{l}\text { - Statement of } \\
\text { financial } \\
\text { position } \\
\text { (balance sheet) }\end{array}$ & 0 & 0 & 0 & 0 & 0 & 0 \\
\hline $\begin{array}{l}\text { - Statement of } \\
\text { profit or loss } \\
\text { and other } \\
\text { comprehensive } \\
\text { income }\end{array}$ & 0 & 0 & 0 & 0 & 0 & O \\
\hline $\begin{array}{l}\text { Statement of } \\
\text { changes in } \\
\text { equity }\end{array}$ & 0 & 0 & 0 & 0 & 0 & 0 \\
\hline $\begin{array}{l}\text { - Statement of } \\
\text { cash flows }\end{array}$ & 0 & 0 & 0 & 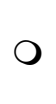 & 0 & 0 \\
\hline $\begin{array}{l}\text { Notes to the } \\
\text { financial } \\
\text { statements }\end{array}$ & 0 & 0 & 0 & 0 & 0 & 0 \\
\hline
\end{tabular}


Q4 Sources of information

We would like to gain insights into the key sources of information which you use in making decisions. Please allocate $100 \%$ among the various sources of information to indicate their importance. Please use the space below to explain your reasons.

Corporate financial statements

Management commentary and analysis including directors' reports

The press, media and other on-line sources

Advisors and analysts' reports

Others, please indicate the other sources and their weightings

Q5 Interest in supplementary information

Do you use or require any supplementary information that is not included in current corporate financial reports?

Y Yes

No

Q6 Usefulness of supplementary information

Please indicate the level of usefulness to you, of supplementary information in financial reports, using the scale 1 to 5 , where 1 indicates very low usefulness and 5 indicates very high usefulness. Please support your views with comments in the spaces provided.

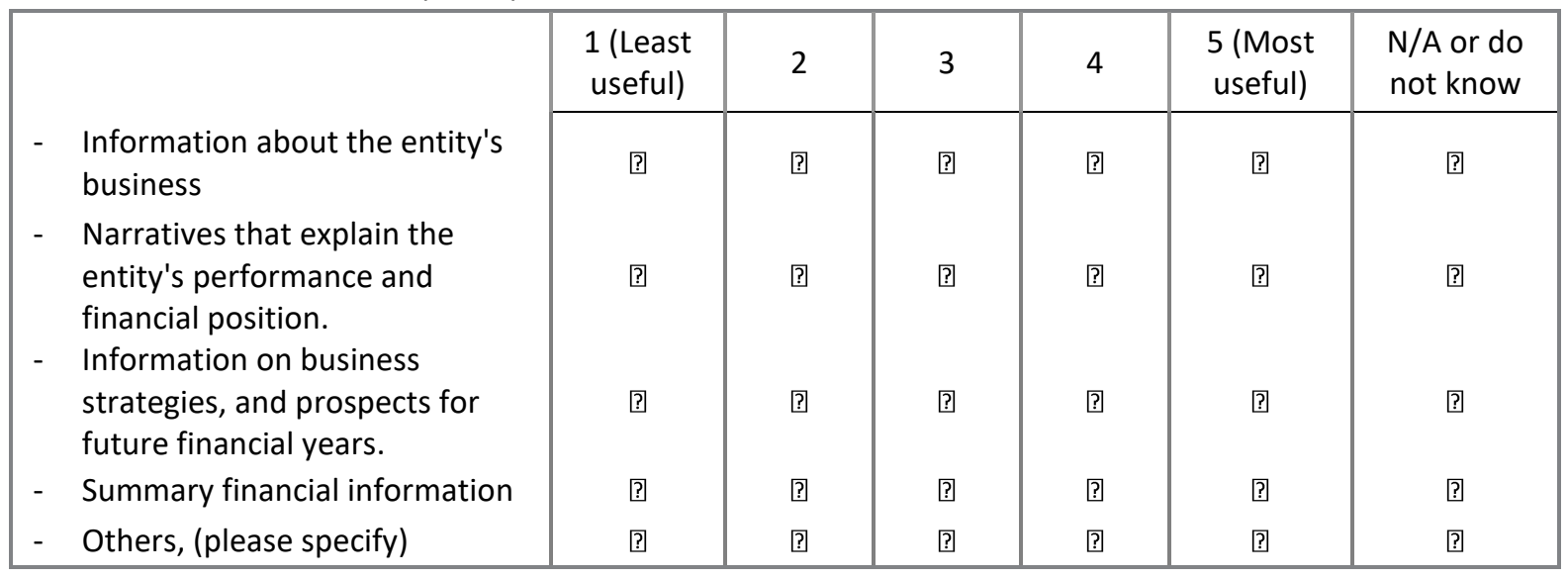




\section{References}

Abdel-Khalik, A.R., Collins, A.W., Shields, P.D., Snowball, H.D., Stephens, G.R., and Wragge, H.J. 1983, Financial Reporting by Private Companies: Analysis and Diagnosis, Financial Accounting Standards Board, Stamford, CT.

Anderson, R. 1981, 'The Usefulness of Accounting and Other Information Disclosed in Corporate Annual Reports to Institutional Investors in Australia', Accounting and Business Research, 11 (44): 259-265.

Anderson, H., Chan, H., Faff, R., and Ho, Y.K. 2012, 'Reported Earnings and Analyst Forecasts as Competing Sources of Information: A New Approach', Australian Journal of Management, 37 (3): 333-359.

Andon, P., Baxter, J., and Chua, W.F. 2015, 'Accounting for Stakeholders and Making Accounting Useful', Journal of Management Studies, 52 (7): 986-1002.

Andriani, Y., Kober, R., and Ng, J. 2010, 'Decision Usefulness of Cash and Accrual Information: Public Sector Managers' Perceptions', Australian Accounting Review, 20 (2): 144-153.

ASIC Regulatory Guide 247 March 2013, Effective Disclosure in an Operating and Financial Review, Australian Securities and Investment Commission, Sydney.

Baker, H.K. and Haslem, J.A. 1973, 'Information Needs of Individual Investors', The Journal of Accountancy, 136 (5): 64-69.

Barker, P. and Noonan, C. 1996, 'Small Company Compliance with Accounting Standards: The Irish Situation'. Available at: http://doras.dcu.ie/2113/1/DCUBS Research Paper Series 10.pdf

Barnett, A. and Leoffler, K. 1979, 'Readability of Accounting and Auditing Messages', The Journal of Business Communication, 16 (3): 49-59.

Brochet, F., Jagolinzer, A.D. and Riedl, E.J 2013, 'Mandatory IFRS Adoption and Financial Statement Comparability', Contemporary Accounting Research, 30 (4): 1373-1400.

Carsberg, B., Page, M., Sindall, A., and Waring, I. 1985, Small Company Financial Reporting, The Institute of Chartered Accountants in England and Wales, London. 
Chartered Financial Analyst (CFA) UK Financial Reporting and Analysis Committee 2015, Annual Survey on Financial Reporting and Analysis.

Chandra, G. 1974, 'A Study of the Consensus on Disclosure Among Public Accountants and Security Analysts', The Accounting Review, 49 (4): 733-742.

Chenhall, R.H. and Juchau, R. 1977, 'Investor Information Needs - An Australian Study', Accounting and Business Research, 7 (26): 111-119.

Cheung, E. and Lau, J. 2016, 'Readability of Notes to the Financial Statements and the Adoption of IFRS', Australian Accounting Review, 26 (2): 162-176.

Conesa, I.M., and Martinez, E.O. 2004, 'International Financial Analysis and the Handicap of Accounting Diversity', European Business Review, 16 (3): 272-291.

Coombes, R.J. and Stokes, D.J. 1985, 'Standard-Setters' Responsiveness to Submissions on Exposure Drafts: Australian Evidence', Australian Journal of Management, 10 (2): 31-45.

Courtis, J.K. 1982, 'Private Shareholder Response to Corporate Reports', Accounting and Finance, $22(2):$ 53-72.

Courtis, J.K. 1986, 'An Investigation Into Annual Report Readability and Corporate Risk-Return Relationships', Accounting and Business Research, 16 (64): 285-294.

Courtis, J.K. 1995, 'Readability of Annual Reports: Western Versus Asian Evidence', Accounting, Auditing \& Accountability Journal, 8 (2): 4-17.

Deloitte 2011, 'Navigating Annual Reporting: Financial Reporting Checklist for Directors'. Available at: http://www2.deloitte.com/content/dam/Deloitte/il/Documents/risk/CCG/ financial reporting committee/navigating annual reporting.pdf

Eierle, B. and Haller, A. (2009). Does size influence the suitability of the IFRS for Small and Medium-sized Entities? - Empirical evidence from Germany. Accounting in Europe, 6(2) :195230

European Financial Reporting Advisory Group (EFRAG) 2009, 'The Needs of Users of Financial Information, A User Survey'. Available at: http://www.iasplus.com/en/binary/efrag/ $\underline{\text { 0905userneeds.pdf }}$ 
Elliot, W.B., Hodge, F., and Jackson, K.E. 2008, 'The Association Between Non-Professional Investors' Information Choices and Their Portfolio Returns: The Importance of Investing Experience', Contemporary Accounting Research, 25 (2): 473-498.

External Reporting Board (XRB) 2016, 'Information Needs of Users of New Zealand Capital Markets Entity Reports'. Available at: https://xrb.govt.nz/information-hub/current-researchreports/

External Reporting Board (XRB) 2017, 'Information and Assurance Needs of Users of Tier 2 For-Profit Entity Financial Reports', XRB, Wellington, New Zealand. Available at: https://www.xrb.govt.nz/information-hub/current-research-reports/

Financial Accounting Standards Board 2010, 'Conceptual Framework of Financial Reporting', Statement of Financial Accounting Concepts No. 8, FASB, Norwalk, CT.

Financial Executives Research Foundation (FERF) 2006, 'What do Users of Private Company Financial Statements Want?'. Available at: http://www.pcfr.org/downloads/ 05_07_meet_materials/ferf_private_co_user_survey.pdf

Gassen, J. and Schwedler, K. 2010, 'The Decision Usefulness of Financial Accounting Measurement Concepts: Evidence From an Online Survey of Professional Investors and Their Advisors', European Accounting Review, 19 (3): 495-509.

Handley, K., Wright, S. and Evans, E. 2017, 'SME Reporting in Australia: Where to Now for Decision-usefulness?', Australian Accounting Review, doi:10.1111/auar.12179.

Healy, P. 1977, 'Can You Understand the Footnotes to Financial Statements?', Accountants Journal, 56: 219-222.

Horton, J., Serafeim, G. and Serafeim, I. 2013, 'Does Mandatory IFRS Adoption Improve the Information Environment?', Contemporary Accounting Research, 30 (1): 388-423.

International Accounting Standards Board 2010, Conceptual Framework for Financial Reporting 2010, IFRS Foundation, London, U.K.

Jermakowicz, E.K. and Gornik-Tomaszewski, S. 2006, 'Implementing IFRS from the Perspective of EU Publicly Traded Companies', Journal of International Accounting, Auditing and Taxation, 15 (2): 170-196. 
Jermakowicz, E.K., Prather-Kinsey, J. and Wulf, I. 2007, 'The Value Relevance of Accounting Income Reported By DAX-30 German Companies', Journal of International Financial Management and Accounting, 18 (3): 151-191.

Laswad, F. and Botica Redmayne, N. 2015, 'IPSAS or IFRS as the Framework for Public Sector Financial Reporting? New Zealand Preparers' Perspectives', Australian Accounting Review, 25 (2): $175-184$.

Lee, T.A. and Tweedie, D.P. 1975a, 'Accounting Information: An Investigation of Private Shareholder Usage', Accounting and Business Research, 5 (20): 280-291.

Lee, T.A. and Tweedie, D.P. 1975b, 'Accounting Information: An Investigation of Private Shareholder Understanding', Accounting and Business Research, 6 (21): 3-17.

Li, F. 2008, 'Annual Report Readability, Current Earnings, and Earnings Persistence', Journal of Accounting and Economics, 45 (2): 221-247.

Maingot, M. and Zegbal, D. 2006, 'Financial Reporting of Small Business Entities in Canada', Journal of Small Business Management, 44 (4): 513-530.

McNally, G.M., Eng, L.H. and Hasseldine, C.R. 1982, 'Corporate Financial Reporting in New Zealand: An Analysis of User Preferences, Corporate Characteristics and Disclosure Practices for Discretionary Information', Accounting and Business Research, 13 (49): 11-20.

Morris, R.D., Gray, S.J., Pickering, J. and Aisbitt, S. 2013, 'Preparers' Perceptions of the Costs and Benefits of IFRS: Evidence From Australia's Implementation Experience', Accounting Horizons, 28 (1): 143-173.

Navarro-García, J.C. and Bastida, F. 2010, 'An Empirical Insight on Spanish Listed Companies' Perceptions of International Financial Reporting Standards', Journal of International Accounting, Auditing and Taxation, 19 (2): 110-120.

Page, J.M. 1984, 'Corporate Financial Reporting and the Small Independent Company', Accounting and Business Research, 14 (55): 271-282.

PricewaterhouseCoopers (PwC) 2011, 'The Role of the Annual Report'. Available at: http://www.pwc.com/en GX/gx/audit-services/corporate-reporting/publications/investorview/pdf/pwc-role-of-the-annual-report.pdf 
PricewaterhouseCoopers (PwC) 2014a, 'Corporate Performance: What do Investors Want to Know? Reporting Adjusted Performance Measures'. Available at: http://www.pwc.ch/ user content/editor/files/publ corp/pwc corporate performance what do investors wa nt to know.pdf

PricewaterhouseCoopers (PwC) 2014b, 'Corporate Performance: What do Investors Want to Know? Innovate Your Way to Clearer Financial Reporting'. Available at: https://www.pwc.com/gx/en/audit-services/corporate-reporting/publications/investorview/assets/pwc-investor-survey-ir-september2014.pdf

Quagli, A. and Paoloni, P. 2012, 'How is the IFRS for SME Accepted in the European Context? An Analysis of the Homogeneity Among European Countries, User and Preparers in the European Commission Questionnaire', Advances in Accounting, Incorporating Advances in International Accounting, 28 (1): 147-156.

Rankin, M., Stanton, P.A., McGowan, S.C., Ferlauto, K. and Tilling, M. 2012, Contemporary Issues in Accounting, Wiley, Milton, Australia.

Stent, W. and Dowler, T. 2015, 'Early Assessments of the Gap Between Integrated Reporting and Current Corporate Reporting', Meditari Accountancy Research, 23 (1): 92-117.

Vergoossen, R.G.A. and Amsterdam, V.U. 1993, 'The Use of Perceived Importance of Annual Reports by Investment Analysts in the Netherlands', European Accounting Review, 2: 219-244.

Watts, R.L. 1977, 'Corporate Financial Statements, A Product of the Market and Political Processes', Australian Journal of Management, 2 (1): 53-75.

Weetman, P. (2018), 'Financial reporting in Europe: Prospects for research', European Management Journal, 36 (2): $153-160$.

Yap, C. 1997, 'Users' Perceptions of the Need for Cash Flow Statements-Australian Evidence', European Accounting Review, 6 (4): 653-672 


\section{Figure 1}

\section{New Zealand's For-Profit Reporting Environment}

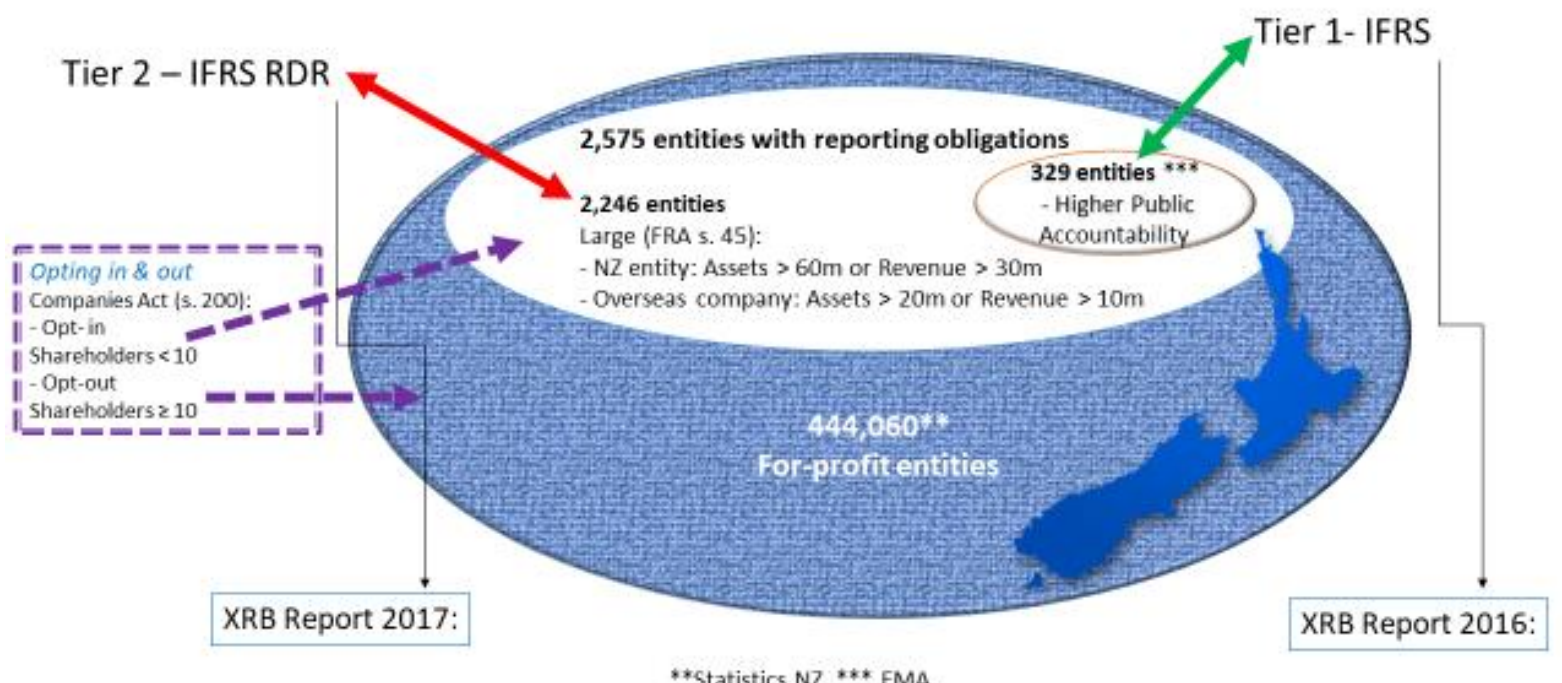


Figure 2: User type and group

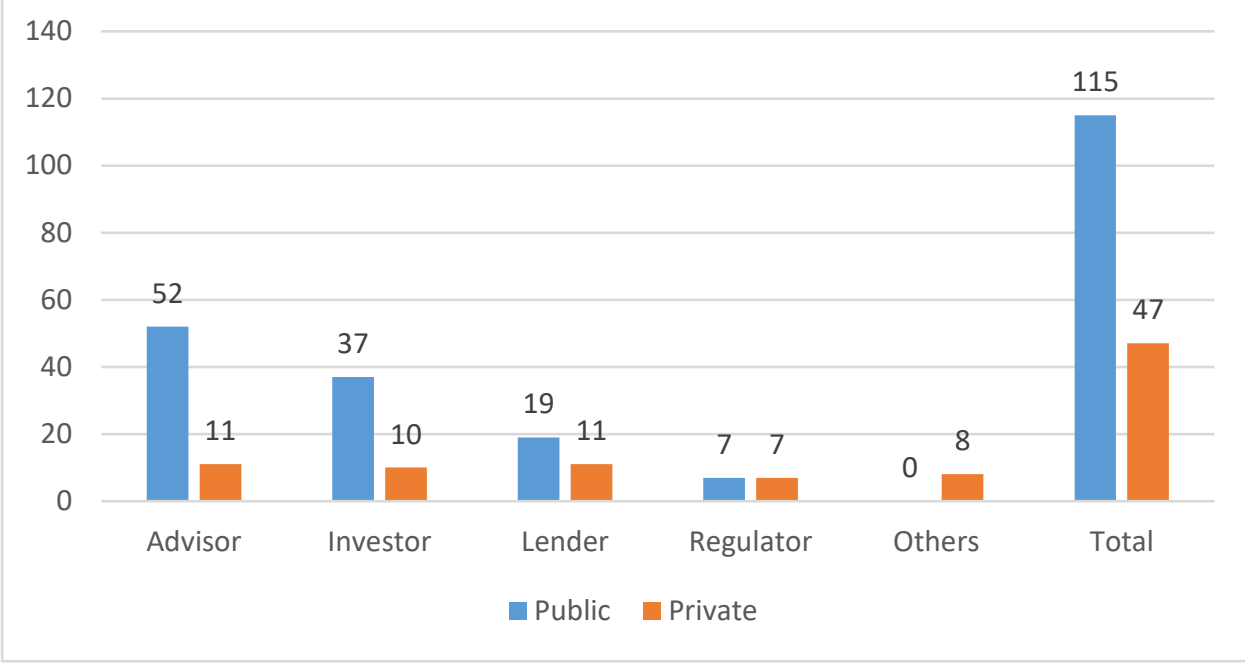


Figure 3: The importance of sources of information

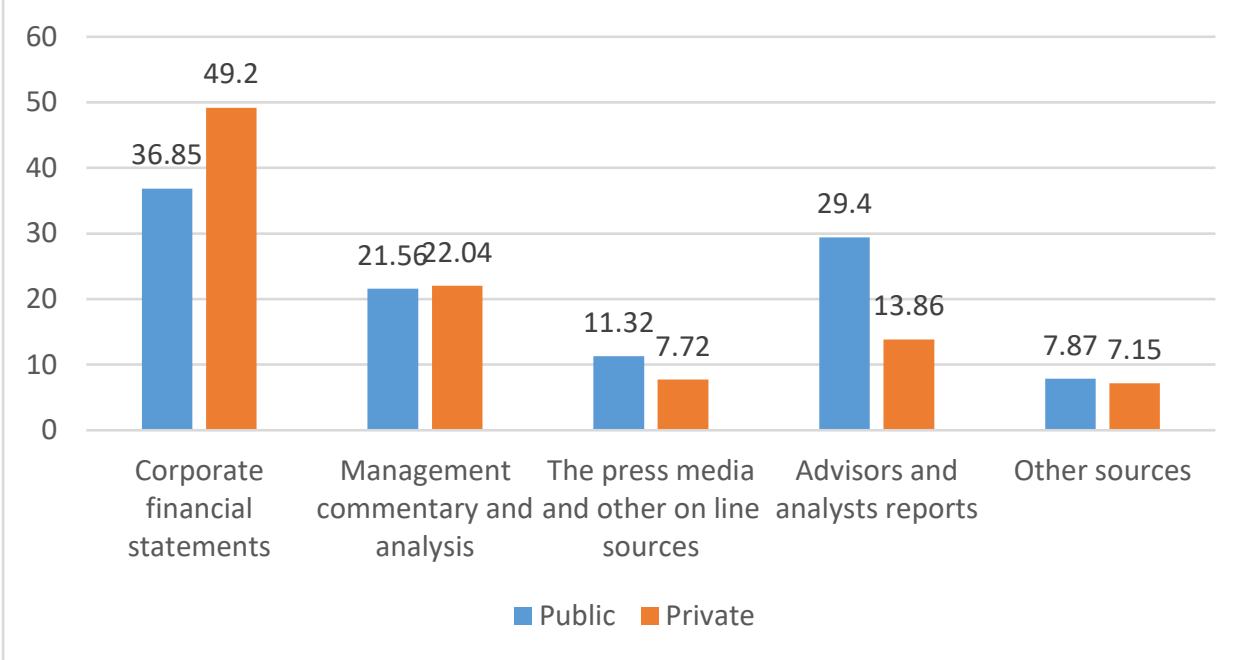




\title{
Are Financial Reports Useful? The Views of New Zealand Public Versus Private Users
}

\author{
Ehalaiye, D
}

2020-03

22/04/2023 - Downloaded from MASSEY RESEARCH ONLINE 